\title{
Envisioning Gender Justice in Our Hearts and Minds: A Promising Tool for Change
}

\author{
Alemnew Gebeyehu Dessie \\ Debre Markos University, School of Law, Debre Markos, Ethiopia \\ Email address: \\ lawalemgebeyehu@gmail.com \\ To cite this article: \\ Alemnew Gebeyehu Dessie. Envisioning Gender Justice in Our Hearts and Minds: A Promising Tool for Change. Humanities and Social \\ Sciences. Vol. 3, No. 5, 2015, pp. 177-184. doi: 10.11648/j.hss.20150305.13
}

\begin{abstract}
In the quest for making legal sense of human rights to equality for all and bringing sustainable change in the lives of human kind, bringing justice to the lime light of our hearts and minds is mandatory. In marching to growth and development, foremost, everyone must accept that human beings are created equal and lives should be treated undifferentiated. However, our world has lived in a state of selfishness; women (our beloved mothers, sisters, daughters, wives and relatives) remained marginalized for long years of time. This is a very disappointing act against the law of nature, or morality, and the positive law (in the sense of human rights to equality). In addition, it is an overt self-defeating move towards our endeavor for change and sustainable development. Therefore, this essay is purported to briefly and concisely depict the sensitivity of gender justice to human rights to equality and sustainable development. That it making gender justice a reality is vital for bringing comprehensive change decisive for betterment of human life. As such, this essay is going to curse the past mischief, and advocates and plausibly argues the need for the conception of gender justice in our every walk of life.
\end{abstract}

Keywords: Gender Justice, Human Rights, Women’s Empowerment, Sustainable Development

\section{Introductory Remarks}

The basic reason and major cause of women's serious marginalization is the long lived practice of male dominated patriarchal society. They were deprived their equal right in marriage and divorce, right to access, control, and possess land though Land is one of the most significant resources to women's empowerment, ${ }^{1}$ political participation and leadership, as well as their social life in the society. Cultural practices were discriminatory and stereotyped which are highly harmful to women.

However, in the recent times, such humiliating activities are lessened. And what makes such problem not to be crashed is the existence of deeply rooted and widespread harmful traditional and cultural practices, gender insensitive legal frameworks and policies weak to ensure the protection of the rights of women. But, this does not mean that the change brought has not been satisfactory in recent times. ${ }^{2}$

Most countries' legislations are not human rights-friendly, and some other little better ones suffer from implementation problems. For this, enactment of many gender-sensitive policies and laws across numerous African countries is required. And such gender-sensitive and sound policies and laws should be implemented in a way they can bring positive practical effect on women. Besides, empirical assessment of laws and policies implementation status quo is rewarding. ${ }^{3}$

In an effort to put/bring gender justice into our hearts and minds and produce gender-responsive persons and build gender-sensitive justice sectors and women associations is helpful. For this, there needs to establish fair, accessible, trusted and accountable justice sectors/institutions. Therefore, peoples within a society that can promote gender equality, ensure equal access to judicial processes, identify and address problems and gaps within existing laws, mechanisms and processes can be devised to promote genderjustice. ${ }^{4}$

Unless otherwise, such conceptual and practical gaps narrowed, and if we don't play our own best role to bring gender justice, our endeavor or striving to achieve sustainable development is challenging. That is why the Millennium Development Goals (MDGs) has set its target for 2015 on eradicating extreme poverty and hunger, improve maternal health and reduce child mortality, promotion of gender equality and empowerment of women, and other related issues which directly or indirectly implicates gender justice having ascertained gender equality and empowerment of women. ${ }^{5}$

Up to date, many United Nations (UN) conferences held 
recurrently in multifarious places for advocating that women's empowerment is central to sustainable development For example, The Copenhagen Declaration of the World Summit on Social Development (WSSD) was aimed at the recognizing empowerment of people, especially women to strengthen their own capacities. All these pillar worldwide conferences and summits are playing the women-inclusive objective of development. This can be done by realizing their empowerment via full participation in the formulation, implementation and evaluation of decisions determining the functioning and well-being of societies. Besides, the report of the United Nations Fourth World Conference on Women is also the other significant international platform for action on agenda for women's empowerment. ${ }^{6}$

\section{Theoretical and Inspirational Frameworks on Gender and the Law}

\subsection{General Remarks}

The current legal regime that purports to protect women rights one way or the other bases itself on theoretical and inspirational works of various feminist scholars. Their works more often than not intend to uncover the root causes of women disadvantaged positions and propose possible alternative legal solutions which can at best curb out the women's gender based problem. This article, therefore, is dedicated to deal with some of theoretical and inspirational framework of gender and law. Accordingly, the foundation of women legal subordination, the principle of nonsubordination, the principle of formal equality and substantive equality, different voices and autonomy will be discussed.

\subsection{Foundation of Women Legal Subordination}

The ideas about women that took hold into this century subordinated women in mutually reinforcing ways. Perhaps the most enduring conceptual basis for women's subordinate legal and social status is the assumption that while men represent the norm of the fully human being, women represent a deviation -- sometimes superior, usually inferior, but always "different." Some explanations of women's inherent difference have focused on the biological, others on the moral, and still others on the economic or social. ${ }^{7}$

The perception of women as inherently different has resulted in systematic legal disadvantages for women as compared with men. It has also disadvantaged some groups of women who most closely conform to the expected norms. Women's differences sometimes have been used to gain legal protections. Even these measures, however often contribute to women's subordinate status by narrowing their options and reinforcing their use as scapegoats for society's ills, such as poverty, immortality, and crime.

Another foundation of women's subordinate status is the concept of women as property. Under the legal regime of slavery, slave women's bodies were directly exploited for economic profit. In addition to providing field labor and domestic labor to their white owners, slave women could expect to be sexually exploited; indeed, there was an economic incentive for such exploitation, because the child of a slave woman was legally a slave as well. After slavery was formally abolished by the Thirteenth Amendment, black women and other women of color were channeled into lowpaying personal service jobs that left them without access to training or capital.

A free white woman in the eighteenth century who married did not face these depredations, yet she found her legal and economic existence virtually suspended - merged with that of her husband. Until the advent of married women's property acts and earnings statutes in the nineteenth century, the marital unity doctrine meant that a married white woman was incapable, except under certain circumstances recognized at equity, of making contracts or wills, owning property, retaining control of her" separate estate," testifying as a witness in court against her husband, or retaining her own name. Even as equitable principles evolved and statutes were enacted to protect women's economic interests, or the interests of those with whom they or their husbands transacted business, these laws were interpreted in ways that reinforced women's economic dependency on men.

The definition of sexual norms is also a powerful tool of subordination. The sexual exploitation of slaves, the nineteenth century "cult of motherhood," control of women's reproduction through bans on birth control and abortion, domestic violence, and the laws against miscegenation, were among the many ways sexual norms were used to establish and reinforce gender subordination which, again, often intersected with race and class subordination.

A foundation for women's subordination which helps to draw together some bases for women's subordination into a coherent whole is the "separate spheres" ideology. This ideology defines a male sphere that is "public" -- one concerned with the regulated world of government, trade, business, and law, from which women long were largely excluded. Women did not win the vote in the United States until the passage of the Nineteenth Amendment in 1920, after a long and hard-fought battle and well after male former slaves were enfranchised at the end of the Civil War.

Even after suffrage, women were routinely excluded from serving on juries well into the 1960's. Women's participation in the military has traditionally been limited to auxiliary positions, secure from the opportunities for glory, if not from danger. Since traditionally a public role was not contemplated for women, they were systematically discouraged from obtaining higher education, from joining the professions, and from running businesses except as helpmates to their husbands.

The separate spheres ideology also defined a "private" sphere, encompassing the unregulated realm of home, family, and child-rearing. Women attained what status they had through the legally sanctioned family, and without it, they could expect economic hardship, pity, and suspicion. Yet it was woman's "place" in the private sphere that justified her 
exclusion from the public sphere, and under the marital unity doctrine, her husband retained ultimate authority over her even in that domain. The separate spheres ideology not only rationalized women's exclusion from political and economic self-rule and their assignment to dependent and subservient roles; it also helped to obscure that subordination by defining women's confinement to matters of home and family as "natural." In addition, it obscured distinctions between women based on race and class. For example, some family lives were made possible by domestic servants, who spent their working lives caring for other women's husbands and children at the expense of their own. ${ }^{8}$

\subsection{Non-Subordination}

The non-subordination perspective on women and law shifts the focus of attention from gender-based difference to the imbalance of power between women and men. This perspective, also known as dominance theory, makes the relevant inquiry not whether women are like, or unlike, men, but whether a rule or practice serves to subordinate women to men. Accordingly, similarities and differences between women and men are important under this theory not as givens that produce certain expected, rational consequences in the law, but as part of a larger system of categories and concepts designed to make women's subordination seem natural and legitimate.

As developed by Catharine MacKinnon, dominance theory offers a way of understanding not just the situations of elite women, who are well represented in liberal feminism, and not just women's situation as a function of class, as presented by socialist feminism, but the situation of all women -- hence the term "unmodified" or "unqualified" feminism.

Catharine MacKinnon has identified legal subordination as the ability of those with power -- men -- to identify their own point of view as "point-of-viewlessness."Legal materials relating to sexual harassment, pornography, domestic violence, and heterosexuality reflects the notion of non subordination. The non-subordination theory's claim that the law defines sex and sexual difference in ways that mask the universality of men's point of view and naturalize women's relative powerlessness in this society.

It is no accident that this theory relates to sexual behavior - in and outside traditional families, in the workplace, in educational institutions, in commerce, and elsewhere. This is largely because it is in the sexual realm that dominance theory has the most new and different to offer to an analysis of the relationship between gender and law. With respect to sex-based discrimination in hiring, promotion, and equal pay in the workplace, in access to education and other public benefits, traditional equality theory appears to have achieved benefits for women which are desirable even from a dominance theory perspective.

MacKinnon's complaint with equality theory, of whichever variety, is that while it is adequate to handle certain marginal exceptions -- e.g., privileged women who fit the male profile -- it is insufficient to address the central inequalities faced by women -- sexual violence and abuse, poverty, deprivation of control over reproductive decisions, and so on. To get at these questions, MacKinnon moves beyond questions of sameness and difference to the construction of women's sexuality, which she finds to be at the core of the processes through which these more central inequalities are sustained. This construction is made visible in the sexual acts of pornography, sexual harassment, domestic violence, and other, but according to MacKinnon it underlines women's subordination and devaluation more generally in all spheres of women's lives. ${ }^{9}$

\subsection{Formal Equality}

Formal equality is a principle of equal treatment: individuals who are alike should be treated alike, according to their actual characteristics rather than stereotypical assumptions made about them. It is a principle that can be applied either to a single individual, whose right to be treated on his or her own merits can be viewed as a right of individual autonomy, or to a group, whose members seek the same treatment as members of other, similarly situated groups. What makes an issue one of formal equality is that the claim is limited to treatment in relation to another, similarly situated individual or group and does not extend beyond same-treatment claims to any demand for some particular, substantive treatment.

Some problems of sex equality are masked because the rule or practice is based on criteria that appear to be sexneutral, such as height and weight requirements, but impact disproportionately upon women. While formal equality might appear to provide no grip on such criteria, the principle that likes be treated alike requires that such criteria be justified by the actual requirements of the job, lest stereotyped expectations (airline stewardess = beautiful women; firefighters $=$ strong men) govern what kinds of people have what kinds of job opportunities. Formal equality insists not only that those who are similarly situated be treated alike, but that stereotypes and over-generalizations not dictate who is determined to be similarly situated to whom.

Formal equality applies to sex-based classifications that discriminate against men, as well as those that discriminate against women. In formal equality terms, the goal is equal treatment for all, not just women. Extending formal equality principles to rules that discriminate against men, or favor women, might also be justified on the grounds that rules that appear to benefit women instead promote attitudes and expectations about women, including their dependency or status as victims that disadvantaged them across a wide spectrum of social contexts. Those who offer this rational may favor formal equality as a strategy, but insofar as their choice of principle is based on its woman-centered results or outcomes, they already have their foot in the door of substantive equality.

Aristotle whose work was one of the earliest contributions to Western jurisprudence and legal thought on equality, made the link between equality and justice. "The just" said Aristotle "is the lawful and the equal, and the unjust is the unlawful and the unequal." However as feminists in the West 
have been quick to point out, Aristotle's was a selective concept of justice and equality. Aristotle interpreted equality as sameness of treatment among equals, or treating equals equally or likes alike according to merit and their just deserts The implication is that injustice would not follow when differences were recognized, and the different were treated in an unlike manner.

Aristotle also perceived equality and justice as relevant only to the State, and the political and public sphere. His norm of equality and justice did not prevent recognition of the status quo in slavery, and the patriarchal domination of a family headed by a male. Accordingly, "there can be no injustice in an unqualified sense towards things that are one's own."

Aristotle's concept of equality is also reflected in a fundamental maxim of the Roman law of the Emperor Justinian "render to each his own," or "what he deserved." Equality though equated with justice therefore did not encompass the idea of impacting to achieve equality for all. Equality referred merely to a formal concept of sameness of treatment among persons placed in similar circumstances. The idea that "like should be treated as like," legitimized differences in treatment based on ethnicity or sex. Since men and women were biologically different, and racial characteristics were different, different treatment was not deemed an infringement of equality. This ideology continues to be endorsed sometimes in South Asian countries to differentiate between "equity" and equality, justify discrimination, and resist efforts to integrate the concept of equality for all, and equality for women and men.

These perceptions of justice and a formal model of equality had a profound impact on the manner in which Constitutional jurisprudence on equality in the United States developed. This jurisprudence is particularly relevant for South Asia because it has influenced judicial interpretations and developments in India and Sri Lanka and Indian cases have been followed in other jurisdictions.

The early Constitutional cases in the United States Supreme Court interpreted equality in the context of formal law and policy of the State in government action. The leading case of Plessey v Ferguson (1896) refused to strike down public transport legislation that provided for segregation between blacks and whites on the ground that segregation did not imply inferiority of either group, but provided separate but similar facilities for each group. This formal interpretation of equality was based on the Aristotelian idea that different treatment of unalike can be equal and "likes should be treated as alike."

Formal equality by emphasizing sameness in treatment without regard to impact and circumstances also denied the significance of disadvantage that could result in different outcomes, when people placed in different circumstances were treated in the same manner. As Anatole France has pithily remarked, this approach reflected "the majestic equality of the law, which forbids rich and poor alike sleeping under bridges, to beg in the streets and to steal their bread."
The formal approach to equality provided an opportunity to perpetuate conservative attitudes and a "protectionist" approach to women as a vulnerable group in the community. These two perspectives were combined to justify the nineteenth century laws in the US preventing women from voting and entering the legal profession. In Bardwell $\mathrm{v}$ Illinois (1873) for instance, the US Supreme Court rejected the claim of a female attorney Myra Bardwell that a refusal to admit her to practice law in the State of Illinois was a denial of equality and discrimination on the basis of her sex. Justice Bradley stated that:

"Man is or should be woman's protector and defender. The natural and proper timidity and delicacy which belongs to the female sex evidently unfits it for many of the occupations of civil life .... The paramount destiny and mission of women are to fulfill the noble and benign office of wife and mother."

The public private dichotomy that Aristotle referred to and the "like must be treated as like" concept justified treating men and women differently, and entrenched gender bias and exclusion in what were perceived as gender neutral laws and policies.

It took many decades to challenge the exclusive focus on formal equality, in interpreting equality. In the great civil rights case of Brown v Board of Education (1955), the U.S. Supreme Court decided that "separate educational facilities (for blacks and whites) are inherently unequal." The case has been hailed as transforming the jurisprudence on equality and discrimination in the USA. Brown $\mathrm{v}$ Board of Education introduced the concept that the circumstances in which people were placed must be taken into account, and that equality must be interpreted according to impact and the context and reality of disadvantage. The decision paved the way for moving from Aristotle's model of formal equality to equality in substance or substantive equality, with an interpretation of equality that assessed outcome and result.

In time substantive equality was interpreted to legitimize taking special measures on behalf of disadvantaged groups so as to provide a level playing field, and address the inequalities and disadvantages of context. The Bake Case (1978) decided that the disadvantage of race could be taken into account as a factor in determining preferential or special policies based on race in university admissions. The Supreme Court of the United States developed a jurisprudence that gave limited recognition to substantive equality, by developing the idea of equal opportunity, to address the context of disadvantage exclusion and discrimination. Substantive equality was understood within the familiar standard of equal treatment.

Introducing special measures (or affirmative action) to prevent discrimination in impact was controversial, because this could not easily be reconciled with the concept of equal treatment in a formal sense. Special measures have therefore been described as "preferential treatment" or "reverse discrimination" that required strict scrutiny by the Courts, and special justification. The traditional constitutional doctrine of reasonable, non arbitrary classification of the 
group that is treated differently, and connection to a legitimate objective that is to be achieved by the classification has been applied to determine whether the special measures are legal.

However the movement away from formal equality did not in general include interpretations that addressed the broad context or reality of disadvantage, and the inequality in impact, outcome or result because of these circumstances. Affirmative action or special schemes for women in the workplace to give them promotion prospects not available to men have been recognized. Yet a comprehensive approach to the reality of disadvantage that women suffer because of their situation has not been adopted. When, for instance, employment benefits for both men and women require a specified period of service, the reality could be that most women workers would not qualify for these benefits, because they have been employed for that period as casual workers. This type of female specific inequality in result is not generally incorporated into the concept of substantive equality of opportunity. The emphasis continues to be on equality of opportunity for men and women, a position justified on the argument that 'equality of opportunity may not result in equal treatment, but it does respect every persons' right to treatment as an equal.

\section{Substantive Equality}

\subsection{Feminist Interpretation of Substantive Equality}

Feminist research and scholarship from the nineteen sixties addressed the limitations of the formal equality and equal opportunities concept from the perspective of gender equality. It was also pointed out that the arguments for and against protective legislation within the paradigm of formal equality failed to address the broader need to take account of women's reality in the workplace, and interpret equality with due regard to eliminating the disadvantages they experienced as women. It was pointed out that these disadvantages were imposed and had little relevance to stereotypical views on feminine vulnerabilities. It was argued that if these disadvantages were eliminated, there would be no further need for "protection." There was a growing understanding that the male standard of sameness used in determining formal equality of treatment and opportunities and discrimination, failed to take account of women's experiences and so perpetuated the disadvantage they suffered because they were women.

The new scholarship on stereotypical gender roles and attitudes and their discriminatory impact on women emphasized that women were not vulnerable by nature, but suffered from imposed disadvantage. The deconstruction of laws and legal concepts that were gender biased, entrenching patriarchy and male perspectives, contributed to challenging a model of formal and even substantive equality that made men the reference point for women's equality. It is this initiative that had a profound impact in developing the original limited concept of substantive equality to accommodate a broader concept of eliminating the disadvantages that women have suffered as women.

The feminist critique of formal equality drew on the original doctrine of substantive equality and developed it in a manner that enabled it to be absorbed into national laws and the international law on equality and women's rights. The gender sensitive concept of substantive equality that addressed the realities of context and determined equality and discrimination against women in terms of eliminating disadvantage in result was strengthened by jurisprudence on equality in the Canadian Supreme Court.

In cases originating from a leading case, Andrews v Law Society of British Columbia (1989), the Supreme Court, in interpreting the right to equality in the Canadian Charter of Rights and Freedoms, rejected the traditional model of formal equality. A Canadian statute limited entry into the legal profession to Canadian citizens. Andrews was able to show that though qualified to enter the legal profession he was disadvantaged because he was not a citizen. The Supreme Court of Canada interpreted equality so as to take into account context, the reality of disadvantage suffered by the victim of discrimination, and impact. In adopting this interpretation, the court moved from the idea of achieving formal equality of treatment and opportunity to focus on equality of result.

The concept of substantive equality determined by outcome and result has now been incorporated in many countries constitutions. This concept of equality is going beyond formal legal equality. The reality of disadvantage and context, taking results and impact into account, is addressed in determining whether there is discrimination. Equality is linked to other human rights. The goal is thus not merely formal equality of treatment but extends to eliminating discrimination of outcome or result. The impact of laws, policies and programs to eliminate discrimination must be evaluated from this perspective. Since gender based discrimination in substance violates the norm of fairness, it becomes difficult to argue that a standard of equity (fairness) is different from equality.

The recognition that formal equality, often manifested in a gender-neutral framing of policy or law, may not be sufficient to ensure that women enjoy the same rights as men. That is to say, framing a policy for "people" implicitly including women and men, while not excluding women per se, may result in a de facto discrimination against women. This is because of the fact that women and men are not the same. Not only is there a significant biological difference between women and men (women bear children, not men), but gender differences (socially-created differences between men and women upheld by ideology and perpetuated by socialization processes) also result in norms and assumptions made about what women and men's roles in society are, what their capabilities, needs and interests are, which influence both policy-making and its implementation. Differences between women and men whether based on biological (sex) difference or socially created (gender) differences results in women's asymmetrical experience of: 
- Disparity; and

- Disadvantage

Initiatives for the realization of women's rights need to compensate for or cater to the difference, disparity or disadvantage. This means taking into account the ways in which women are different from men, and ensuring that these differences are acknowledged and responded to by policy or legal interventions and programs. However, how this is done, depends on what kind of analysis informs the content of policy and programs. All approaches that take into account differences between women and men are not immediately favorable to women - in fact, they could be discriminatory in effect, if not in intention. In order to be able to intervene effectively in favor of gender equality, it is important to have a conceptually sound understanding of what or why differences between women and men exist.

The substantive model of equality that the convention promotes, adopts the corrective approach. The recognition of difference in the convention is based on the premise that women are in an unequal position because they face current discrimination, or they come bearing the effects of past discrimination, or that the environment, at the family and public levels, is hostile to women's autonomy. This approach assesses specific provisions or rules to see whether the rule in question contributes to women's subordination in the short or long term, whether it builds on existing subordination, thus reinforcing it, or whether it helps to overcome that subordination. Under the corrective approach, if there are job opportunities that require night work, there would be public policies or laws that require employers to make some provision that would make it safe for women to work at night instead of placing a ban on night work. This could be the provision of transport for women workers etc.

Furthermore the corrective approach requires that socially constructed differences such as the traditional roles ascribed to women and men as well as cultural practices that see women as inferior need to be changed.

In particular, the convention recognizes that the function of child bearing is borne exclusively by women and presents a case for viewing child bearing as a social function which cannot be used as a basis for discrimination against women.

The corrective or substantive approach recognizes that in order to redistribute benefits equally between women and men, approaches to promoting women's rights must transform the unequal power relations between women and men in the process. For this to happen, policies, laws and programs must aim to provide the following:

- Enabling conditions, in the form of the basic social, economic and cultural contexts within which women may be able to lead their lives with dignity; and

- Affirmative action in the form of temporary special measures where women's needs are specially recognized and catered for in the context of employment, education, financial services, politics and all other spheres of life in order to enable women to overcome barriers that are historical or those that arise from male domination in the system.
By way of conclusion, substantive equality requires the State to ensure a broad approach to equality that includes:

- Equality of opportunity;

- Equality of access to the opportunity; and

- Equality of results.

\subsection{Different Voices of Cultural Feminism}

The concern for women's equality is filtered through a commitment to preserving and expanding the benefits of certain characteristics historically associated with women. Within different voice theory (also referred to as cultural feminism, or relational justice, or difference theory), women's differences are viewed less as problems to be addressed than as valuable resources that might serve as a better model of social organization and law than existing "male" characteristics and values. These differences are said to include greater sense of interconnectedness, a priority on relationships over rights, and a preference for more contextualized, less abstract forms of reasoning. Besides, women are said to favor an "ethic of care" over justice or rights models of morality.

The central theme of different voice theory lies on the question whether there are "women's values" that can be affirmatively promoted for the general betterment of society, and if so, can this be done without reinforcing the role these values have played in maintaining women in subordinate positions in the society.

Many advocates of the theories view different voice theory with suspicion, because of the risk that the attribution of certain common values to women will reinforce the ideologies of subordination that those theories are intended to dispel. At the same time, almost everyone assumes that the increasing presence of women in law schools, in law practice, in elected offices, on juries, and on the bench will have a positive effect on how law is taught, practiced, applied and made -- all assumptions most readily identified with relational theories of justice. Can this apparent contradiction be reconciled? Does it matter whether the purported differences between women and men are based in biology or are a result of social conditioning?

The tension between assertions of sameness and assumptions of difference present in much feminist theory provides the occasion for a general exploration of the impact of women in all roles in the legal system. It also facilitates further examination of the relationship between theory and practice: Is the insistence that women are like men a truth upon which theory should be built or a strategy to achieve a form of justice which must be justified on other premises?

\subsection{Autonomy}

Many legal standards assume that individuals are capable of having "intent," of exercising "choice" or "consent," and of acting and thinking like a "reasonable" person, and require juries and judges to make findings accordingly. Women's advocates make similar assumptions when they argue that women should have greater personal autonomy, freedom to 
make their own choices, and power to control their own lives

A series of challenges to the law's assumption that individuals act autonomously and to the law's ability to make objective determinations about the individual's intent, consent, and ability to make rational choices were stimulated by intellectual currents in other disciplines known as "postmodernism." The post-modern view of the individual or the "legal subject" opposes the Enlightenment view of the stable, coherent self, capable of reason and "privileged insight into its own processes and into the 'laws of nature," with a more complicated view of the individual as one who is constituted multiple institutional and ideological forces that, in various ways, overlap, intersect, and even contradict each other.

These structures produce "the subject's experience of differentiated identity and... autonomy," but a misleading one, for under the postmodern view this experience of what is real, rational, or, in some transcendent sense, true. Some of these and related themes were brought into law in the 1970's through what became known as the critical legal studies movement (CLS), a loose coalition of academic scholars who worked on many theoretical fronts to challenge the law's claim to neutrality, rationality, and objectivity, as well as the hierarchical structures of democratic society and the poverty of individualism. In some cases, CLS critiques led to paralysis inaction, for the assault on the objective foundations of liberal legal thought seemed to undermine any foundations for an alternative framework as well. If neutrality, and objectivity, and even autonomy are impossible, it was hard to see how any reforms of existing legal structures, however radical, could be defended.

In the hands of scholars of gender and law, however, postmodern insights have not ended efforts to enhance the autonomy and freedom of women but rather have invigorated them. Legal activists and scholars who have enlisted postmodern critiques in the effort to end women's subordination have shown that better understanding of the limits of individual subjectivity and free choice can lead to better strategies for maximizing autonomy. The proposition that autonomy is impossible was restated by some scholars and women's advocates as a practical observation that choice is a relative concept, and that, in some matters at least, more is better than less. At the same time, the meaning of autonomy has been expanding beyond the right to be free from interference by others to include the ability to flourish among and in relation to others.

Many "anti-essentialist" critiques implicitly or explicitly call for a more sophisticated understanding of relations of power. When we think about oppression, we tend to assume there are people and groups who are oppressed and people and groups who are oppressors.

But is it possible for an individual or a group of people to be oppressed in some ways and privileged in others? And is it possible for a person to benefit from oppression without actively or even knowingly being "an oppressor?" This recognition may make the analysis of gender more difficult, but it may also open up possibilities for seeing new connections between forms of oppression that initially look very different. ${ }^{10}$

\section{The Role of Gender Justice in Marching to Sustainable Development/Change}

Due to the fact that the meaning and essence of gender has an interdisciplinary nature, the issue of gender justice is an all-touching and wide concept. Hence, it quests to elaborate in light of legal, social, cultural, legal, philosophical, anthropological, economic, political...etc sphere of studies. Here the following better provides its meaning in brief and concise manner. It says "[g]ender justice can be defined as the protection and promotion of civil, political, economic and social rights on the basis of gender equality."7 As the preceding quote explains, gender justice on the human rights to equality, It relied on taking a gender perspective on the rights themselves, and the likely access and obstacles to the enjoyment of these rights for both women, men, girls and boys. For this, adopting gender-sensitive strategies for protecting and promoting them is crucial. ${ }^{11}$

Next, it is possible to understand that working on gender justice is the hub of sustainable development. When men and women laced at equal opportunity and destiny to realize their end; a firm and productive hand to derive a social, economical and political change can be obtained. And this is possible by the time gender equality has entrenched in the cultural, social, political, and economical spheres of life. As opposed to this, history tells us that women were forced to leave their house without a valid divorce, coerced to evict their land holdings or other endowments, victims of sexual violence (rape, kidnapping and abduction, illegal trafficking, domestic violence like hitting, stabbing, emotionally abused...etc), serve without any wage or inadequate wage...etc evil acts has violated their indignity, honor, and bodily integrity.

All such dreadful practices unduly erode the nature of human kind. When one questions her/himself: is there any one of us who does not have a mother, sister, wife, daughter, friend, and relatives? Is there anyone who does not want to have empowered mother, sister, wife, daughter...etc or is there anyone who does not want to have a better home, food, cloth...etc? For sure and unless s/he is cruel and selfish, no one answers to the negative. If so, no one is strange to know and to appreciate the fact and it is convincing to argue that we all have to give a meaning to gender justice which is the basic tool to put on the ground the marvel notions of human rights to equality.

All in all, gender justice advocates avoiding the inequalities between women and men, which were found and prevailed in the family, the community, the society, and the market and the state. It also deserves mainstreaming institutions like justice, land, education, parliament...etc authorities to enact and implement gender justice wise laws and policies. And in the event of failure to do so, there must be essence of accountability for tackling the injustice and 
discrimination caused women's impoverishment. Consequently, women should be shield from violence and have an enough path to public services (education, health, food...etc), land and favorable job, participate and involve in decision making agenda starting from home to local, national, regional and international arenas. ${ }^{12}$

\section{Concluding Remarks: Key Devices to Nurture Gender Justice}

In a need to reach at a new world where gender justice is blossomed and considerable change is brought, developing key problem solving solutions and consistent enforcement is required from all. However, these solutions only be effected if and only if we developed gender justice in our hearts and minds-believing in gender equality (gender balance). Women's participation in all spheres of decision-making and policy formulation is a manifestation of justice and redress and an important asset of real democratization. ${ }^{13}$ If so, it is believed to mainstream gender issues in making and enacting policies and laws in every aspect of life.

To nurture or bring gender justice as we contemplate is not easy for all of us and not similarly working for all. Rather, it needs to adapt ideal solutions preferable to the status quo of gender justice in a certain area. Because ways to confront gender injustice and to wage redressing mechanisms as per to the situations should be designed depending on the gravity of past injustice and the resources we have. For instance, nurturing gender justice in post-conflict regions is not easy and timely achievable though laws and policies outlined streamlining gender justice. Plus to this, the economic development of a country matters. Meaning, a certain developing country may not be asked to cope up with a developed one in attaining equal level of gender justice. That is neither the State nor its citizens should not wait till things are fulfilled by themselves. But it is expected to try combating injustice that affected women or likely to affect them up to our best end. Because, some nature of human rights (including gender issues) do not give time till an aspired economic development is achieved. They require immediate realization. Hence, especially States should not devise laws or policies concerning gender issues to be realized progressively. And present insufficient economic resources should not be used as justifications or pretext to be relived from the quest for gender justice from the people. Therefore, although socio economic human rights of women believed to take time to their realization, some possible human rights like food, health care, shelter...etc immediate needs fulfillment or realization is compulsory. Thereby, when socio-economic rights fulfilled women become empowered since gender discrimination is also resulted from lower per capita income, life expectancy, and literacy. ${ }^{14}$

\section{References}

[1] Teshome Yirgu Bayu. Socio-cultural and Policy Related Constraints to Women's Land Right: A Case Study from Gamo Highland, SW Ethiopia. Humanities and Social Sciences. Vol. 3, No. 4, 2015, pp. 149-154. doi: 10.11648/j.hss.20150304.14.

[2] Endalcachew Bayeh. Human Rights in Ethiopia: An Assessment on the Law and Practice of Women's Rights. Humanities and Social Sciences. Vol. 3, No. 2, 2015, pp. 8387. Doi: 10.11648/j.hss.20150302.13.

[3] Mary Hallward-Driemeier and Ousman Gajigo; Strengthening Economic Rights and Women's Occupational Choice the Impact of Reforming Ethiopia's Family Law pp.2.

[4] Agneta M. Johannsen. "Training Resources on Justice Reform and Gender." In Gender and Security Sector Reform Training Resource Package, edited by Megan Bastick and Kristin Valasek. Geneva: DCAF, 2009.

[5] The Gender and Media Diversity Journal; countdown to 2015, The SADC Gender Protocol Work...Changing lives Changing institutions Changing nations Changing SADC ...pp.10.N.

[6] Gender and the Law Distance Teaching Material, Bahir Dar University, Faculty of Law, (2009).

[7] Ibid.

[8] Supra, see note 6 and 7 above.

[9] G. S. Ogato; The quest for gender equality and women's empowerment in least developed countries: Policy and strategy implications for achieving millennium development goals in Ethiopia, pp.359.

[10] Nahla Valji; Gender Justice and Reconciliation, p.7.

[11] Ibid.

[12] Gender Justice: Key to Achieving the Millennium Development; UNIFEM (United Nations Development Fund for Women) -part of UN women.

[13] Supra, see note, 6 above.

[14] Renee Giovarelli and Susana Lastarria-Cornhiel, Study on Women and Property Rights, Best Project Practice-Produced for review by the USAID for International Development and prepared by ELTAP Project, ARD, Inc.,(October 2006). 